\title{
Ergene Nehir Suyunun Soğan (Allium cepa L.) Kök Ucu Hücrelerinde Genotoksik Etkisinin Değerlendirilmesi
}

\author{
Evaluation Of Genotoxic Effects On Onion (Allium cepa L.) Root Tip Cell Of Ergene River \\ Water
}

\author{
Martin Orlinov KANEV ${ }^{1}$ (ORCID ID: 0000-0001-8482-5074), Kezban ÖZDEMİR ${ }^{1}$ (ORCID ID: 0000-0002-9758-9581), \\ Fulya Dilek GÖKALP² (ORCID ID: 0000-0001-8219-6657) \\ ${ }^{1}$ Trakya Üniversitesi, Fen Bilimleri Enstitüsü Biyoteknoloji ve Genetik Anabilim Dall, 22000, Edirne, Türkiye \\ ${ }^{2}$ Trakya Üniversitesi, Fen Fakültesi Biyoloji Bölümü, 22000, Edirne, Türkiye
}

Öz

Türkiye'de endüstriyel hareketlerin artması ile birlikte, Trakya bölgesinde organize sanayi alanları kurulmuş ve bunun sonucunda özellikle Trakya bölgesini besleyen Ergene Nehri ve çevre alanlarında kirlilik artmıştır. Bu çalışmada, Ergene nehir suyunun Allium cepa L. kök ucu hücrelerinde genotoksik ve sitotoksik etkilerinin araştırılması amaçlanmıştır. Çalışmada Ergene nehir suyundan iki farklı istasyondan aynı dönemde alınan su örnekleri 0.1/100 mL, 1/100 mL, 5/100 mL, 10/100 mL, 20/100 mL ve 40/100 mL konsantrasyonlar ile soğan (Allium сера L.) kök ucu hücreleri 24 saat muamele edilerek sitogenetik anormallikler belirlenmiş ve mitotik indeks hesaplanmıştır. Her iki istasyondan alınan örneklerin, uygulanan tüm dozlarında mitotik anormallikleri kontrole göre anlamlı bir şekilde arttırdığ 1 ve mitotik indeksi anlamlı olarak değiştirdiği belirlenmiştir. En fazla gözlenen mitotik anormallikler kromozomlarda asenkronizasyon, yanlış kutuplaşma ve C-mitozdur. Sonuçlar Ergene nehir suyunun A. cepa testinde genotoksik ve sitotoksik etkili olduğunu göstermektedir.

Anahtar Kelimeler: Ergene Nehri, Allium cepa, sitotoksisite, genotoksisite.

\begin{abstract}
As a result of industrialization movement in Turkey, organized industrial zone have been established in Thrace, and especially pollution reached significant size in there and their surrounding area. In the present study, it was aimed to study the genotoxic and cytotoxic effects of the Ergene River water on Allium cepa root tip cells. In the study, Ergene river water samples taken at the same time from two different stations. Samples were exposed with $0.1 / 100 \mathrm{~mL}, 1 / 100 \mathrm{~mL}, 5 / 100 \mathrm{~mL}, 10 / 100 \mathrm{~mL}, 20 / 100 \mathrm{~mL}$, and 40/100 mL doses for 24 hours on onion (Allium cepa L.) root tip cells, and cytogenetic abnormalities and mitotoic index were investigated. On applied all doses of both stations, mitotic abnormalities were significantly increased compared with control, and mitotic index was significantly changed. The most observed mitotic abnormalities in chromosomes are asencronization, incorrect polarization, and C-mitosis. The results indicated that the Ergene River has genotoxic, and cytotoxic effects on A. cepa.
\end{abstract}

Keywords: Ergene River, Allium cepa, cytotoxicity, genotoxicity

\section{Giriş}

Gelişmekte olan ülkelerde insan nüfusun artması sonucu ortaya çıkan şehirleşme ve endüstrileşme giderek artan kirliliğe neden olmaktadır. Kentsel, endüstriyel ve tarımsal atıklar, yüzey sularında ve sedimentlerde kirliliğin artmasına neden olmakta ve bu durum ekosistem ile ilişkili biyota için tehlike oluşturmaktadır [1]. Genotoksik bileşikler tarafından suların kirlenmesi dünya çapında bir sorundur. Çevre ve su kalitesinin değerlendirilmesinde fiziksel ve kimyasal analizler ile birlikte birçok toksisite ve özellikle genotoksisite testleri birlikte kullanılmaktadır [2].

Tüm dünyada olduğu gibi Türkiye'de de artan endüstrileşme özellikle 1970'ler sonrası Trakya'nın giderek kirlenmesine yol açmıştır. Ergene Nehri, Trakya Bölgesinin 
ortasında yer almaktadır. Endüstriyel, evsel ve tarımsal uygulamalar nehir boyunca devam ettiği için nehre kirleticiler yoğun olarak dökülmektedir. Ergene Nehri, Tekirdağ ilinde bulunan Istranca Dağlarından kaynağını almaktadır. Meriç Nehri ile birleşerek Saroz Körfezinden Ege Denizi’ne dökülmektedir. Uzunluğu $283 \mathrm{~km}$ ve nehir havzası $11,000 \mathrm{~km}^{2}$ dir. Y1llık olarak 1.71 milyar $\mathrm{m}^{3}$ su hacmi mevcuttur (evsel atık suyu $230,000 \mathrm{~m}^{3} /$ gün; endüstriyel atık suyu 330,000 $\mathrm{m}^{3}$ /gün). Ergene Havzasında sanayi tesislerinin yanında çeşitli tarım alanları bulunmaktadır. Bu bölgede konumlanan sanayi kuruluşları çok miktarda su kullanmakta ve kullandıkları bu suyu atık olarak nehre boşaltmaktadırlar. Nehir ile tarım arazileri sulanmakta; tarım arazilerinde yoğun pestisit kullanılmasıyla da yer altı sularına karışarak kirlilik daha da artmaktadır [3, 4]. Dünyada sucul ekosistemlere özellikle nehir sularının kirlenmesine ilgi giderek artmaktadır. Suların kirlenmesi sonucu birçok nehirde canlılık yok olmakta veya azalmaktadır. Ayrıca bu nehirler ile sulanan arazilerde yetiştirilen ürünlerde verim azalmaktadır [5].

Nehir suyu gibi karmaşık çevresel örneklerin değerlendirilmesi ve izlenmesi için mikroorganizmalar ve memeli hücrelerini içeren çeşitli toksisite testleri kullanılmaktadır. Bitki analizleri ağır metaller, hidrofil ve lipofilik kimyasallar dahil olmak üzere birçok çevre kirleticisine oldukça duyarlı olup özellikle karışımlarının potansiyel sinerjik etkilerinin izlenmesi için kullanılmaktadır [6]. Yüksek bitkiler sitolojik analizler için uygundur ve bu bitkilerle yapılan testler diğer biyolojik sistemler ile yüksek derecede ilişki göstermektedir, bu nedenle bitki testlerinin kullanılması genotoksisitenin belirlenmesinde önem arz etmektedir [7]. Soğan (Allium сера) kök ucu hücrelerinde kök morfolojisi ve büyüme, mitotik indeks, mikronükleus, kromozom anormallikleri gibi morfolojik ve sitogenetik faktörler toksik etkinin belirlenmesi için kullanılan parametrelerdir [8]. Allium test gerek kimyasal gerekse fiziksel ajanlara verdiği hassas cevap nedeniyle ekotoksikolojik çalışmalarda sıklıkla kullanılan bir yöntem haline gelmiştir $[\mathbf{9}, \mathbf{1 0}]$.

$\mathrm{Bu}$ çalışmanın amacı, son yıllarda endüstrileşme ve şehirleşme sonucu kirlilik oranı gittikçe artan Ergene nehir suyundan evsel ve endüstriyel atıkların boşaltıldığ 1 iki farklı istasyondan aynı dönemde alınan su örneklerinin Allium cepa kök ucu hücrelerinde genotoksik etkisinin belirlenmesidir.

\section{Materyal ve Metot}

\section{1. Çalışma Alanı ve Örnekleme}

Çalışmada kullanılacak su örnekleri Şekil 1'de gösterilen, Ergene Nehri boyunca kirleticilerin en fazla giriş gösterdiği 2 istasyondan (istasyon 1 Çerkezköy $41^{\circ} 17^{\prime} 00^{\prime \prime} \mathrm{N}-28^{\circ} 00^{\prime} 00^{\prime \prime} \mathrm{E}$; istasyon 2 Muratli $41^{\circ} 10^{\prime} 27^{\prime \prime} \mathrm{N}-27^{\circ} 30^{\prime} 31^{\prime \prime} \mathrm{E}$ ) alınmıştır. Su örnekleri 2012 Temmuz ayında, koyu renkli şișelere eşit hacimde uygun yöntemlerle alınmış ve çalışmanın yapılacağı laboratuvara getirilmiştir.

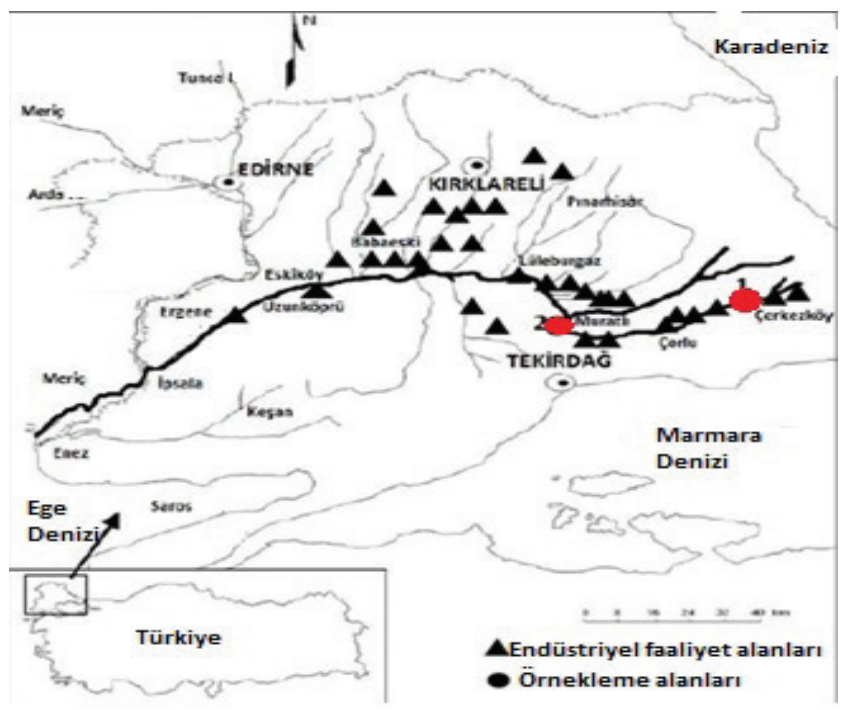

Şekil 1. Ergene Nehri'nden örnek alınan istasyonlar. 1 numaralı istasyon evsel atıkların; 2 numaralı istasyon ise endüstriyel atıkların yoğun olarak boşaltıldığı alanlar olarak seçilmiştir.

\subsection{Deney Dizaynı}

Çalışmada kullanılacak soğanlar, eşit büyüklükte, çimlenmemiş ve morfolojik olarak hasar görmemiş şekilde seçilmiştir. Negatif kontrol olarak saf su ve uygulama dozları olarak saf su ile seyreltilmiş $0.1 / 100 \mathrm{~mL}, 1 / 100 \mathrm{~mL}, 5 / 100$ $\mathrm{mL}, 10 \mathrm{~mL} / 100 \mathrm{~mL}, 20 / 100 \mathrm{~mL}$ ve $40 / 100 \mathrm{~mL}$ Ergene Nehrinden alınan su örnekleri kullanılmıştır. Soğanlar 2-3 cm kök salana kadar saf su içinde bekletilmiş ve sağlıklı çimlenen soğanlar deney materyali olarak kullanılmıştır. Her doz için 5 adet soğan Ergene Nehri suları ile 24 saat $25^{\circ} \mathrm{C}$ 'de muamele edilmiştir. 24 saat sonunda soğan kökleri $1-2 \mathrm{~cm}$ olacak şekilde kesilmiş ve 3:1 alkol:glasiyal asetik asit içine alınmış, 1 gece $+4{ }^{\circ} \mathrm{C}$ 'de bekletilmiştir. Mikroskobik inceleme yapılana kadar kökler \% 70 alkol içinde bekletilmiştir.

\subsection{Su örneklerinde metal düzeylerinin belirlenmesi}

Metal düzeylerinin belirlenmesi amacıyla alınan su örneklerine $5 \mathrm{ml} \mathrm{HNO}$ e eklenmiş ve ölçüm yapılana kadar $-20^{\circ} \mathrm{C}$ 'de bekletilmiştir. Örnekler ICP-MS (Agilent 7700 xx, USA) oto örnekleme sisteminde high matrix yöntemine göre okutulmuştur [11].

\subsection{Kromozom anormalliklerinin belirlenmesi}

Mikroskobik inceleme öncesi kökler saat camına alınmış $\% 2^{\prime}$ lik aseto orsein +1 damla $1 \mathrm{~N} \mathrm{HCl}$ içinde 40 dakika 
bekletilmiştir. Süre sonunda kökler 1 damla \% 2'lik aseto orsein +1 damla $\% 45^{\prime}$ lik asetik asit içinde jilet yardımıyla parçalanmıştır. Kromozom anormalliklerinin belirlenmesi amaciyla her bir konsantrasyon için 5 adet kök ucundan hazırlanan her preparatta 1şık mikroskobunda 300 adet hücre sayılmıştır. Anormallikler mitoz bölünmenin her safhasında aranmış ve en s1k görülen anormalliklerin Olympus CX22 1şık mikroskobunda 40x büyütmede fotoğrafları çekilmiştir.

\subsection{Mitotoik Indeksin Belirlenmesi}

Mitotik indeksin belirlenmesi için her dozda bölünen ve bölünmeyen hücreler olmak üzere 1000 hücre sayılmış ve mitotik indeks için bölünen hücrelerin sayısı kullanılmıştır. Mitotik indeks hesabında;

Mitotik indeks $(\%)=($ Bölünen hücre sayısı / Toplam hücre sayıs1) x 100 formülü kullanılmıştır.

\section{6. İstatiksel Analiz}

Kromozom anormalliklerinin toplam sayısının istatistiki değerlendirmesi SPSS 17.0'da Tukey testi ile; mitotik indeks değerleri yine aynı programda Independent sample $t$ test ile değerlendirilmiştir. Uygulanan dozlar ile oluşan kromozom anormalliklerinin toplam sayısı arasındaki ilişki korelasyon testi ile değerlendirilmiştir.

\section{Sonuçlar}

Çalışmada ICP metodu ile su örneklerinde metal düzeyleri belirlenmiş ve hem evsel hem de endüstriyel atıkların boşaltıldığı alanlardan alınan su örneklerinin Tablo 1'de gösterildiği üzere kıta içi su kaynakları yönetmeliğinde belirlenen değerlere göre alüminyum, mangan, bakır ve arsenik düzeylerinde artış olduğu görülmektedir [12].

Tablo 1. Kıta içi su kaynaklarının içerdikleri metal miktarına göre sınıflandırılarak belirlenmiş kalite kriterleri ve örnek alınan bölgelere ait sularda saptanan metal düzeyleri

\begin{tabular}{|l|c|c|c|c|}
\hline Metaller & 1. İstasyon & $\begin{array}{c}\text { Dahil } \\
\text { Olduğu Su } \\
\text { Sinıf }\end{array}$ & 2. İstasyon & $\begin{array}{c}\text { Dahil } \\
\text { Olduğu } \\
\text { Su Sınıfı }\end{array}$ \\
\hline Alüminyum $(\mu \mathrm{g} \mathrm{Al} / \mathrm{L})$ & 183,309 & $\mathrm{IV}$ & 246,788 & $\mathrm{IV}$ \\
Arsenik $(\mu \mathrm{g} \mathrm{As} / \mathrm{L})$ & 33,442 & $\mathrm{II}$ & 38,734 & $\mathrm{II}$ \\
Bakır $(\mu \mathrm{g} \mathrm{Cu} / \mathrm{L})$ & 30,190 & $\mathrm{II}$ & 3,876 & $\mathrm{I}$ \\
Baryum $(\mu \mathrm{g} \mathrm{Ba} / \mathrm{L})$ & 86,755 & $\mathrm{I}$ & 94,037 & $\mathrm{I}$ \\
Çinko $(\mu \mathrm{g} \mathrm{Zn} / \mathrm{L})$ & 97,244 & $\mathrm{I}$ & 22,269 & $\mathrm{I}$ \\
Demir $(\mu \mathrm{g} \mathrm{Fe} / \mathrm{L})$ & 215,120 & $\mathrm{I}$ & 169,160 & $\mathrm{I}$ \\
Kadmiyum $(\mu \mathrm{g} \mathrm{Cd} / \mathrm{L})$ & 0,018 & $\mathrm{I}$ & $<0.000$ & $\mathrm{I}$ \\
Kobalt $(\mu \mathrm{g} \mathrm{Co} / \mathrm{L})$ & 2,303 & $\mathrm{I}$ & 1,677 & $\mathrm{I}$ \\
Krom $(\mu \mathrm{g} \mathrm{Cr} / \mathrm{L})$ & 12,533 & $\mathrm{II}$ & 12,178 & $\mathrm{II}$ \\
Kurşun $(\mu \mathrm{g} \mathrm{Pb} / \mathrm{L})$ & 2,465 & $\mathrm{I}$ & 0,625 & $\mathrm{I}$ \\
Mangan $(\mu \mathrm{g} \mathrm{Mn} / \mathrm{L})$ & 468,401 & $\mathrm{II}$ & 546,339 & $\mathrm{III}$ \\
Nikel $(\mu \mathrm{g} \mathrm{Ni} / \mathrm{L})$ & 8,390 & $\mathrm{I}$ & 8,253 & $\mathrm{I}$ \\
Selenyum $(\mu \mathrm{g} \mathrm{Se} / \mathrm{L})$ & 1,539 & $\mathrm{I}$ & 1,373 & $\mathrm{I}$ \\
\hline
\end{tabular}

Mitoz bölünmenin tüm safhaları incelenmiş ve gözlenen mitotik anormallikler (Şekil 2) sayılmıştır.

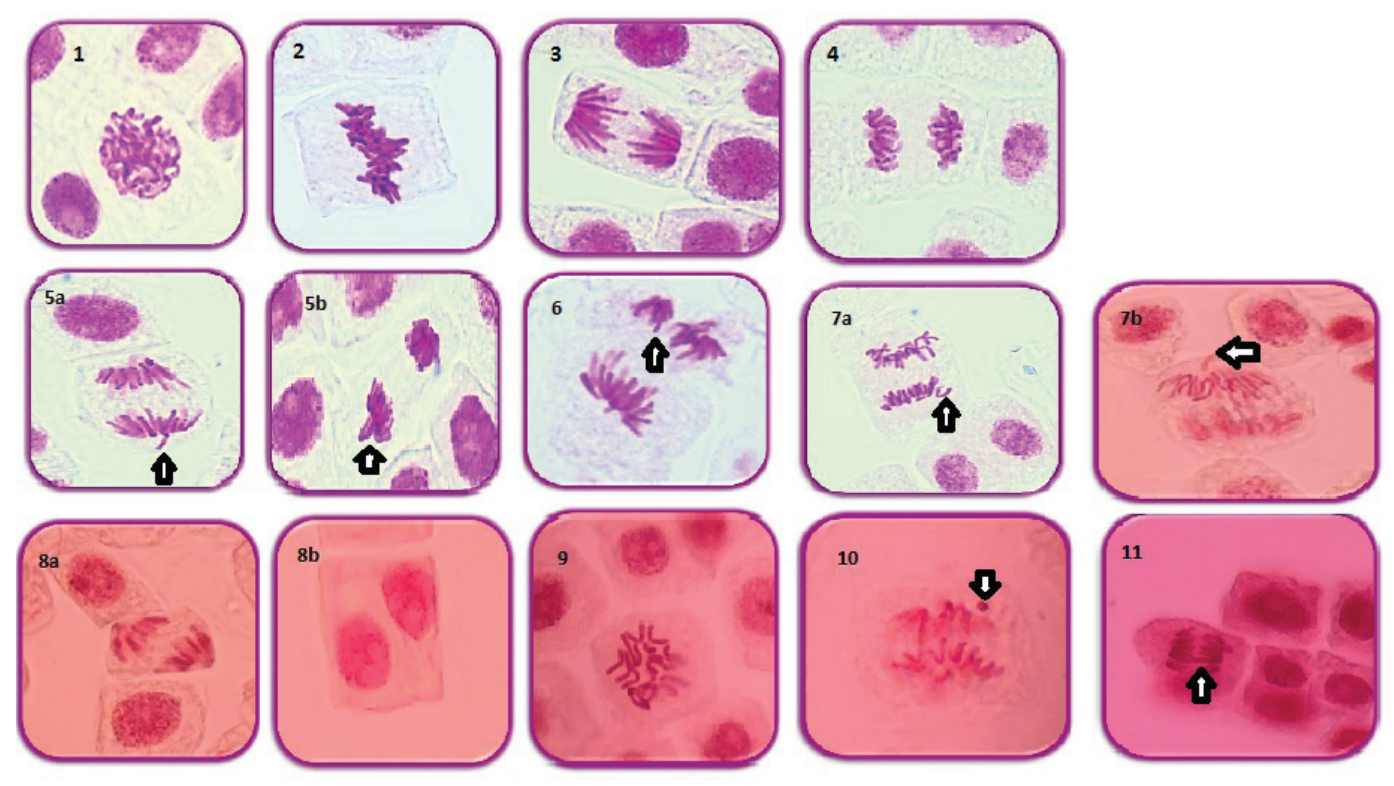

Şekil 2. Ergene nehir suyunun Allium cepa L. kök ucu hücrelerine uygulanmasıyla mitoz bölünmede görülen anormallikler: 1- normal profaz; 2- normal metafaz; 3- normal anafaz; 4- normal telofaz; 5a,5b-kalgın kromatid; 6- çok kutupluluk; 7a,7b- ayrılma; 8a,8b- yanlış kutuplaşma; 9- C-mitoz; 10- fragment; 11- anafazda kromatid köprüsü 
Tablo 2. Ergene nehir suyunun Allium cepa L. kök ucu hücrelerine uygulanmasıyla belirlenen mitotik indeks değerleri ve en çok gözlenen mitotik anormallikler

\begin{tabular}{|c|c|c|c|c|c|c|c|c|c|c|c|c|c|}
\hline Dozlar & İstasyon & $\begin{array}{l}\text { Toplam } \\
\text { Hücre } \\
\text { Sayıs1 }\end{array}$ & $\begin{array}{c}\text { Bölünen } \\
\text { Hücre } \\
\text { Sayıs1 }\end{array}$ & $\begin{array}{c}\text { Mitotik } \\
\text { Indeks } \\
(\%)\end{array}$ & $\begin{array}{c}\text { Asenkro- } \\
\text { nizasyon } \\
(\%)\end{array}$ & $\begin{array}{c}\text { Anafaz } \\
\text { Kromatid } \\
\text { Köprüsü } \\
(\%)\end{array}$ & $\begin{array}{c}\text { C-mitoz } \\
(\%)\end{array}$ & $\begin{array}{c}\text { Fragment } \\
(\%)\end{array}$ & $\begin{array}{l}\text { İleri } \\
\text { gitme } \\
(\%)\end{array}$ & $\begin{array}{l}\text { Kalgin } \\
\text { Kromatid } \\
(\%)\end{array}$ & $\begin{array}{l}\text { MN } \\
(\%)\end{array}$ & $\begin{array}{c}\text { Yanlış } \\
\text { Kutuplaşma } \\
(\%)\end{array}$ & $\begin{array}{c}\text { Toplam } \\
\text { Anormallik } \\
(\%)\end{array}$ \\
\hline \multicolumn{2}{|c|}{ Kontrol } & 2500 & 484 & 19.36 & 4 & 1 & 0 & 0 & 4 & 1 & 0 & 0 & 10 \\
\hline \multirow{2}{*}{$0,1 / 100 \mathrm{~mL}$} & 1 & 2500 & 352 & $14.08^{*}$ & 7 & 3 & 1 & 1 & 7 & 1 & 1 & 0 & $21^{* *}$ \\
\hline & 2 & 2500 & 878 & $35.12 * * *$ & $18^{* *}$ & 0 & $14 * * *$ & 1 & $18^{* *}$ & 0 & 0 & 2 & $53 * * *$ \\
\hline \multirow{2}{*}{$1 / 100 \mathrm{~mL}$} & 1 & 2500 & 289 & $11.56^{* *}$ & 8 & 3 & $6^{*}$ & 2 & 8 & 2 & 1 & 0 & 30 *** \\
\hline & 2 & 2500 & 557 & $22.28 *$ & $11^{* *}$ & 2 & $7 *$ & 1 & $14^{*}$ & 0 & 1 & 3 & $39 * * *$ \\
\hline \multirow{2}{*}{$5 / 100 \mathrm{~mL}$} & 1 & 2500 & 259 & $10.36^{* *}$ & 7 & 1 & $7 *$ & 1 & 7 & 3 & 3 & 1 & $30 * * *$ \\
\hline & 2 & 2500 & 616 & $24.64 *$ & $12 * *$ & 1 & $12 * * *$ & 1 & 12 & 0 & 0 & 0 & $38 * * *$ \\
\hline \multirow{2}{*}{$10 / 100 \mathrm{~mL}$} & 1 & 2500 & 139 & $5.56^{* * *}$ & 9 & 3 & 5 & 2 & 9 & 2 & 1 & $7 *$ & $38 * * *$ \\
\hline & 2 & 2500 & 726 & $29.04 * *$ & $20 * *$ & 1 & $14^{* * *}$ & 3 & $20 * *$ & 0 & 0 & 5 & $63 * * *$ \\
\hline \multirow{2}{*}{$20 / 100 \mathrm{~mL}$} & 1 & 2500 & 107 & $4.28 * * *$ & $11^{* *}$ & 4 & $8^{*}$ & 3 & 11 & 3 & 2 & 4 & $46^{* * *}$ \\
\hline & 2 & 2500 & 928 & $37.12 * * *$ & $17 * *$ & 1 & $13^{* * *}$ & 5 & $17 * *$ & 0 & 2 & 3 & $58 * * *$ \\
\hline \multirow{2}{*}{$40 / 100 \mathrm{~mL}$} & 1 & 2500 & 57 & $2.28 * * *$ & 6 & 3 & $7 *$ & 1 & 6 & 2 & 4 & 4 & $33 * * *$ \\
\hline & 2 & 2500 & 975 & $39 * * *$ & $18^{* *}$ & 3 & $14^{* * * *}$ & 5 & $18^{* *}$ & 1 & 3 & 5 & $67^{* * *}$ \\
\hline
\end{tabular}

Not: Kontrole göre $\mathrm{p} \leq 0.05^{*} ; \mathrm{p} \leq 0.01^{* *} ; \mathrm{p} \leq 0.001^{* * *}$. 1.istasyon evsel bölgeden alınan su örneklerini; 2.istasyon sanayi atıklarının boşaltıldığı bölgeden su örnekleri ifade etmektedir. MN: Mikronükleus.

Mitoz bölünme esnasında kromozomlarda meydana gelen anormalliklerde kontrole göre anlamlı bir artış gözlenmiştir. En fazla gözlenen mitotik anormallikler ise kromozomlarda asenkronizasyon, yanlış kutuplaşma ve C-mitozdur (Tablo 2).

Tablo 2'de verildiği üzere toplam nükleer anormallikler her iki istasyonun tüm dozlarında kontrole göre anlamlı şekilde artmıştır ( $\mathrm{p} \leq 0.001)$. Evsel bölgeden alınan su örnekleri sonucu mitotik indekste meydana gelen değişim ise mitotik indeksin doza bağlı olarak kontrole göre anlamlı şekilde azalmasıdır ( $\mathrm{p} \leq 0.001)$. Sanayi bölgesi su örneklerinde ise doza bağlı olarak mitotik indeksi kontrole göre anlamlı olarak arttırmıştır ( $\mathrm{p} \leq 0.001)$.

Evsel bölge ile sanayi bölgesinin $0.1,10$ ve $40 / 100 \mathrm{~mL}$ dozlarında meydana gelen toplam anormallikler istatistiki olarak birbirinden farklı bulunmuştur (sırasıyla $\mathrm{p}=0.001$; $\mathrm{p}=0.009 ; \mathrm{p}=0.0001$ ). Ayrıca hem evsel hem de sanayi bölgesinden alınan su örneklerinin soğan kök ucu hücrelerinde neden olduğu toplam anormallik sayısında doza bağlı artış olduğu belirlenmiştir ( $\mathrm{p}=0.0001)$ (Şekil 3).

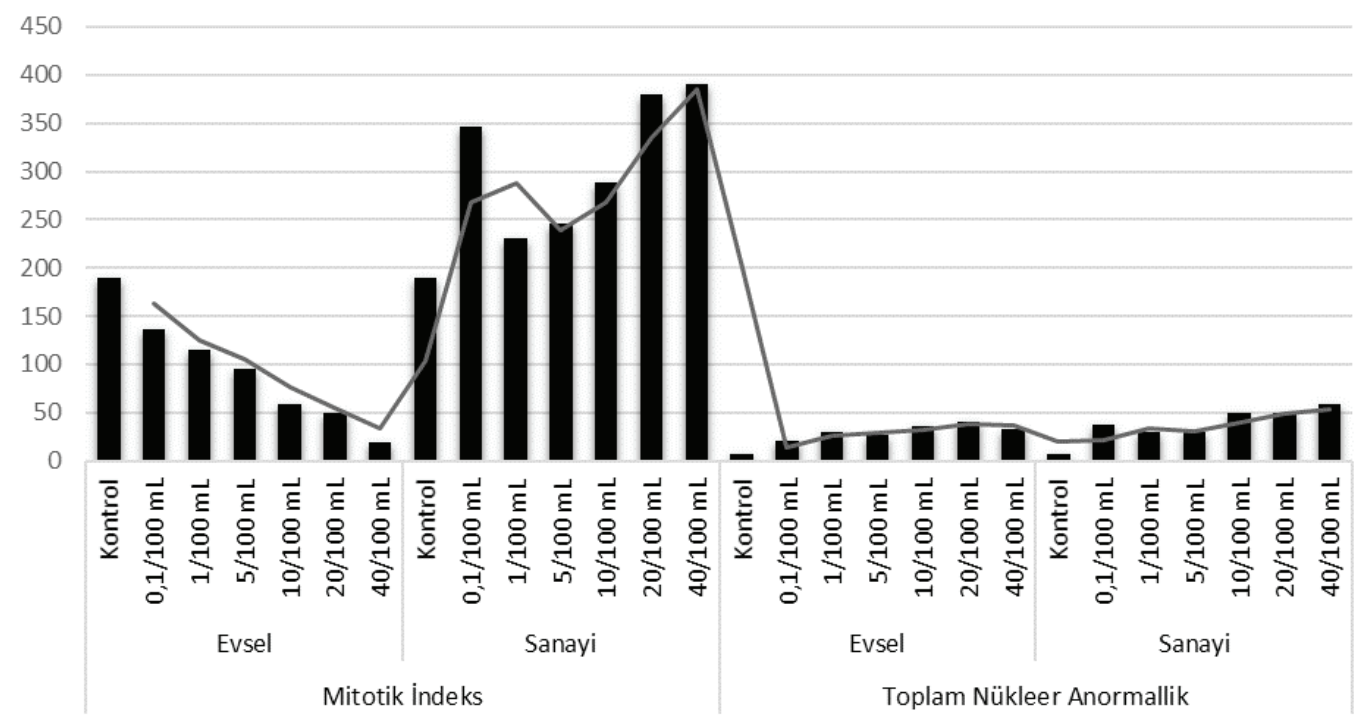

Şekil 3. Soğan kök ucu hücrelerinde muameleler sonucu mitotik indekste meydana gelen değişim ve oluşan nükleer anormallikleri toplamları 
Evsel bölgeden alınan su örnekleri soğan hücrelerinde meydana gelen mitotik indeks azalması ile negatif korelasyon göstermektedir $(\mathrm{r}=-0,986 ; \mathrm{p}=0,0001)$. Dozlar arttıķa mitotik indekste azalma olmuştur. Sanayi bölgesinden al1nan su örneklerinde meydana gelen mitotik indeks değişimi ile dozlar arasinda herhangi bir korelasyon tespit edilememiştir $(r=0,721 ; \mathrm{p}>0,05)$.

\section{Tartışma}

Çalışmanın sonuçları alınan su örneklerinin alüminyum, mangan, bakır ve arsenik dışında diğer metaller bakımından 1.sınıf su kalitesine sahipken, alüminyum bakımından 4.sınıf; mangan bakımından evsel atıkların bulunduğu bölge 2.sınıf, sanayi atıklarının boşaltıldığı alan 3.sınıf; arsenik açısından 2.sınıf ve bakır açısından 1. istasyonun 2.sınıf su kalitesinde olduğu tespit edilmiştir. Bu veriler Ergene Nehir suyunun ölçümü yapılan çeşitli metaller bakımından arsenik ve mangan dışında genel olarak metal kirliliği göstermediğini ifade etmektedir.

Alüminyum, çevrede en sık bulunan ve ciddi sorunlar yaratabilen elementlerden biridir. Genellikle doğal sularda bulunan alüminyum düzeyi kabul edilebilir orandadır çünkü normal hava koşullarında alüminyum çözünmemiş şekilde bulunmaktadır. Yalnızca pH değeri düşük olan sularda ciddi düzeyde alüminyum birikimi tespit edilmiştir [13]. Asidifikasyonun artması ile topraktan da sulara alüminyum geçişi gözlenmektedir. Alüminyum tuzları iyi bir koagülant maddedir. Bu tuzlar koagülasyon ve flokulasyon işlemleri sonucu su içinde kendiliğinden çökemediğinden askıda bulunan partikülleri yumaklar haline getirerek birleştirir ve çöktürülerek filtrelenmesine olanak sağlar. Bu kullanım kolaylığı alüminyumu özellikle sanayi tesislerinin çıkış sularını arıtmak için kullanmaya teşvik etmiştir [14]. Çalışmamızda özellikle sanayi tesislerinin arıtma sularını deşarj ettikleri bölgeden alınan suda normal limitlerin yaklaşık 250 katı fazla oranda alüminyum birikimi olduğu tespit edilmiştir. Mangan ve demir yer altı su kaynaklarında çoğu zaman, yüzeysel sularda ise yılın belirli zamanlarında yüksek konsantrasyonlarda bulundukları için kullanım ve içme suları için sorun teşkil etmektedirler [15]. Çalışmada Ergene nehir suyunda Al miktarının fazla çıkması, koagülant madde olarak kullanılması sebebi ile artış göstermesinden kaynaklanmış olabilir. Ayrıca alüminyum miktarının endüstriyel atıkların fazla olduğu bölgede daha yüksek olması, koagülant madde olarak kullanılmasındaki artışa bağlı olabileceğinin göstergesidir.

Allium test çevresel kirliliğin hızlı bir şekilde belirlenmesi için standart bir yöntemdir. Mutajenik çevresel etkiler, kök şekli ve kök büyümesi gibi makroskobik parametrelerle ve kromozom aberasyon frekansı ile anormal hücre bölünmesi gibi sitolojik parametrelerle analiz edilebilir. Bu testlerin sonuçları, canlı organizmalar üzerinde doğrudan veya dolaylı etkiye sahip çevresel kirleticilerin sitotoksisite, genotoksisite ve mutajenitesini belirlenmesini sağlar [16]. Kromozomların kimyasal veya fiziksel ajanlar ile muamelesi sonucu kromozomlarda kopma ve fragment meydana getirdiği, tarımsal alanda kullanılan pestisitlerin, kromozom kırıklarına neden olduğu bildirilmiştir $[\mathbf{1 7}, \mathbf{1 8}]$. Toprak ve suya karışarak kirliliğe neden olan ağır metal ve tarım ilaçlarının bu ortamlarda yaşayan canlıların kromozomları üzerindeki genetiksel etkileri birçok araştırıcı tarafından çalışılmıştır. Lağım ve endüstriyel atıkların genotoksisitesini belirlemek için Allium kök ucu hücrelerinde yapılan çalışmada anafazdaki normalliklerin oranının arttığı bulunmuştur. Sanayi atıkları ile kirlenmiş atık su çamurunun Allium cepa üzerindeki etkisi incelemiş ve çamurdaki ağır metallerin oluşturduğu kirliliğin kromozomlarda köprü, fragment ve diğer hasarları önemli oranda arttırdığını gözlenmiştir [19]. Şehir atık sularında farklı dezenfektanların mutajenik ve toksik etkisini inceleyen araştırmacılar, Allium cepa'da dezenfektan eklenmiş atık suyun kromozomal anormalliği arttırdığını gözlemişlerdir [20]. Benzer şekilde Ergene Nehir suyunun Secale cereale kök ucu hücrelerinde çeşitli kromozom anormalliklerine neden olduğu gösterilmiştir [21]. Çalışmanın sonuçları önceki çalışmaları destekler niteliktedir ki; endüstriyel ve evsel bölge atık suları $A$. cepa testinde toplam nükleer anormallik oranını kontrole göre arttırmış ve genotoksik etkili olduğu saptanmıştır.

Bölünme indeksi toksisite testlerinde uygulanan en temel yöntemlerden biri olup sitotoksisite göstergesidir. Evsel, tarımsal, endüstriyel faaliyetler sonucu ağır metallerin, tarım ilaçlarının ve deterjanların suya karışmasıyla oluşan su kirliliğinin mitotik indeks üzerindeki etkileri farklılık göstermektedir. Allium testi kullanarak yapılan çalışmada, atık suların bulunduğu nehir kollarından alınan örneklerin mitotik indeksi düşürdüğü, kolların nehre karıştı̆̆ 1 noktalardan alınan örneklerin ise herhangi bir değişmeye neden olmadığ bildirilmiştir [22]. Yapılan bir çalışmada Büyük Menderes ile sulanan Aydın bölgesindeki toprak örnekleri Allium test sistemi ile değerlendirilmiş ve mitotik indekste anlamlı azalmalar tespit edilmiştir [23]. Atık su çamuru ile yetiştirilen Allium cepa'da yapılan çalışmada mitotik indekste kontrole göre önemli bir değişim gözlenmemiştir [18]. Pestisitlerle kontamine olmuş sı̆̆ kaynak suyunda Allium cepa yetiştirilmiş, suyun genotoksisitesinin belirlendiği çalışmada, pestisitlerle kontamine olmuş bölgeden alınan su örneklerinde, kontamine olmamış bölgeye oranla mitotik indekste herhangi bir değişim gözlenmemiştir [24]. Çalışmada evsel bölgeden alınan su örnekleri $A$. серa kök ucu hücrelerinde 
doza bağlı olarak bölünme indeksini düşürmüş ancak sanayi bölgesinden alınan su mitotik indekste artışa neden olmuştur. Diğer çalışmalarda olduğu gibi bu çalışmada da MI'in bölgeye ve su içeriğinin metal ve kimyasallarına göre bitki meristematik dokularında bölünme indeksini değiştirebileceği gözlenmiştir. Araştırmada endüstriyel atık su A. ce$p a$ 'da MI'i arttırmasına rağmen kök hücrelerinde genotoksisite göstergesi olan nükleer anormallikleri de arttırmıştır. Evsel bölge suyuna göre sanayi suyunda daha fazla nükleer anormallik belirlenmesinin nedeni en fazla gözlenen anormallikler olan asenkronizasyon ve C-mitoza evsel bölge suyunun daha fazla sebep olmasından kaynaklanabilir. Suda bulunan bazı bileşiklerin iğ ipliği üzerinde etkili olmuş olabilir ki, sitotoksik etkiden dolayı toplam anormallik say1sında artış gözlenmektedir. Kovalchuk ve ark. (1998)'e göre sitotoksisite, mitotik indeksteki bir azalma ve aynı zamanda C-mitozlu hücreler, multipolar anafazlar, yapışkan ve dağınık kromozomların frekansında artma olarak tanımlanmaktadır [25]. Ancak diğer nükleer anormalliklerin gözlenmesi genotoksik olduğunu göstermektedir. Bolle ve ark. (2004), toksisitenin daima genotoksisite ile ilişkili olmadığını bildirmiştir [26].

Çalışmanın sonucunda, evsel atıkların boşaltıldığı bölgeden alınan su örneklerinin A. cepa testinde kök uçlarında mitotik indekste kontrole göre anlamlı azalmaya sebep olduğu belirlenmiştir. Sanayi atıklarının yoğun boşaltıldığ bölgeden alınan su örneklerinin ise mitotik indeksi arttırmasına rağmen asenkronizasyon ve C-mitoz gibi anormalliklere neden olarak sitotoksik etki gösterdiği saptanmıştır. Seçilen her iki istasyondan alınan su örnekleri kontrole göre mitoz bölünmede anlamlı derecede kromozom anormalliklerine neden olarak genotoksik etki göstermiştir. Sonuçlar Ergene Nehrinin endüstriyel, tarımsal ve evsel atıklar nedeni ile ekotoksik etkileri bulunduğunu göstermektedir. Kirletici kontrolü ele alınarak yeni düzenlemeler yapılması ve önlemler alınması önerilmektedir.

\section{Kaynaklar}

[1] Barberio, A., Barros, L., Voltolini, J. C., \& Mello, M. L. (2009). Evaluation of the cytotoxic and genotoxic potential of water from the River Paraiba do Sul, in Brazil, with the $\mathrm{Al}$ lium cepa L. test. Braz J Biol, 69(3), 837-842.

[2] Kohlpoth, M., Rusche, B., \& Nusse, M. (1999). Flow cytometric measurement of micronuclei induced in a permanent fish cell line as a possible screening test for the genotoxicity of industrial waste waters. Mutagenesis, 14(4), 397-402.

[3] Kocaman, H., Koldere Akın, Y., \& Oğuzhan, A. (2011). Trakya'da Ergene Nehri kirliliğinin tarım üretimine olan etkisi: Edirne örneği. Karadeniz Fen Bilimleri Dergisi, 2(5), 89-104.
[4] Ordu, Ş., \& Demir, A. (2007). Determination of water quality of Ergene River by planning environmental information system. Sigma Journal of Engineering and Natural Sciences, 25(1), 101.

[5] Mehdi, B., Lehner, B., Gombault, C., Michaud, A., Beaudin, I., Sottile, M. F., \& Blondlot, A. (2015). Simulated impacts of climate change and agricultural land use change on surface water quality with and without adaptation management strategies. Agriculture Ecosystems \& Environment, 213, 47-60.

[6] Chandra, S., Chauhan, L. K., Murthy, R. C., Saxena, P. N., Pande, P. N., \& Gupta, S. K. (2005). Comparative biomonitoring of leachates from hazardous solid waste of two industries using Allium test. Sci Total Environ, 347(1-3), 4652. doi: 10.1016/j.scitotenv.2005.01.002

[7] Athanasio, C. G., Pra, D., \& Rieger, A. (2014). Water quality of urban streams: the Allium cepa seeds/seedlings test as a tool for surface water monitoring. ScientificWorldJournal, 2014, 391367. doi: 10.1155/2014/391367

[8] Ozkara, A., Akyil, D., Eren, Y., Erdogmus, S. F., Konuk, M., \& Saglam, E. (2015). Assessment of cytotoxic and genotoxic potential of pyracarbolid by Allium test and micronucleus assay. Drug Chem Toxicol, 38(3), 337-341. doi: 10.3109/01480545.2014.966831

[9] Cresencio, C., Abelada, J., Apostado, R.,.Hernando, B., Lador, J., Obenza, O., Presilda, C. \& Havana, H. (2017). Allium cepa test: an evaluation of genotoxicity. Proceedings of the International Academy of Ecology and Environmental Sciences, 7(1), 12-19.

[10] Tedesco, S. \& Laughinghouse, H.D. (2016). Bioindicator of genotoxicity: the Allium cepa test. Environmental Contamination, 137-156.

[11] Proper, W., McCurdy, E. \& Takahashi, J. (2014). Performance of the Agilent 7900 ICP-MS with UHMI for high salt matrix analysis. Application note.

[12] Yönetmelik. (2015). Yüzeysel su kalitesi yönetimi yönetmeliğindedeğişiklik yapilmasinadair yönetmelik. Resmi Gazete: Orman ve Su İşleri Bakanlığı. Sayı:29307.

[13] Alberti, G., D’Agostino, G., Palazzo, G., Biesuz, R., \& Pesavento, M. (2005). Aluminium speciation in natural water by sorption on a complexing resin. J Inorg Biochem, 99(9), 1779-1787. doi: 10.1016/j.jinorgbio.2005.06.017

[14] Sinha, R., Mathur, S., \& Brighu, U. (2015). Aluminium removal from water after defluoridation with the electrocoagulation process. Environ Technol, 36(21), 2724-2731. doi: 10.1080/09593330.2015.1043958

[15] Britt, R. D., Suess, D. L., \& Stich, T. A. (2015). An Mn(V)oxo role in splitting water? Proc Natl Acad Sci U S A, 112(17), 5265-5266. doi: 10.1073/pnas. 1505223112

[16] Laughinghouse, H. D. t., Pra, D., Silva-Stenico, M. E., Rieger, A., Frescura, V. D., Fiore, M. F., \& Tedesco, S. B. (2012). Biomonitoring genotoxicity and cytotoxicity of Microcystis aeruginosa (Chroococcales, cyanobacteria) using the Allium 
cepa test. Sci Total Environ, 432, 180-188. doi: 10.1016/j.scitotenv.2012.05.093

[17] Türkoğlu, Ş., \& Koca, S. (1999). The effects of paraquat (gramoxone) on mitotic division, chromosomes and DNA amount in Vicia faba L. C.Ü.Fen-Edebiyat Fak. Fen Bilimleri Dergisi, 21.

[18] Wang, J. J., Cheng, W. X., Ding, W., \& Zhao, Z.-M. (2006). The effect of the insecticide dichlorvos on esterase activity extracted from the psocids, Liposcelis bostrychophila and $L$. entomophila. Journal of Insect Science, 4(23), 5.

[19] Rank, J., \& Nielsen, M. H. (1998). Genotoxicity testing of wastewater sludge using the Allium cepa anaphase-telophase chromosome aberration assay. Mutat Res, 418(2-3), 113-119.

[20] Monarca, S., Feretti, D., Collivignarelli, C., Guzzella, L., Zerbini, I., Bertanza, G., \& Pedrazzani, R. (2000). The influence of different disinfectants on mutagenicity and toxicity of urban wastewater. Water Research, 17, 4261-4269.

[21] Bekoğlu Y1lmaz, D. (2013). Ergene nehri suyunun Secale cereale L. tohumunun çimlenmesi ve kök ucu mitoz bölünme üzerine etkisi. Trakya Üniversitesi Fen Bilimleri Enstitüsü.
[22] Evseeva, T. I., Geras'kin, S. A., \& Shuktomova, II. (2003). Genotoxicity and toxicity assay of water sampled from a radium production industry storage cell territory by means of Allium-test. J Environ Radioact, 68(3), 235-248. doi: 10.1016/S0265-931X(03)00054-7

[23] Şahin, Z. (2008). Büyük menderes nehri ile sulanan aydın bölgesi'ndeki toprakların genotoksisitesinin Allium test sistemi ile belirlenmesi. Adnan Menderes Üniversitesi Fen Bilimleri Enstitüsü.

[24] Kong, Z. M., Zang, Y., \& Wu, Q. L. (1998). Monitoring the genotoxicity of Lake Taihu, using two kinds of micronucleus tests. Environ Pollut, 99(2), 279-283.

[25] Kovalchuk, O., Kovalchuk, I., Arkhipov, A., Telyuk, P., Hohn, B., \& Kovalchuk, L. (1998). The Allium cepa chromosome aberration test reliably measures genotoxicity of soils of inhabited areas in the Ukraine contaminated by the Chernobyl accident. Mutat Res, 415(1-2), 47-57.

[26] Bolle, P., Mastrangelo, S., Tucci, P., \& Evandri, M. G. (2004). Clastogenicity of atrazine assessed with the Allium cepa test. Environ Mol Mutagen, 43(2), 137-141. doi: 10.1002/ em.20007 